\title{
On the activity and specificity of cardosin B, a plant proteinase, on ovine caseins
}

\author{
Sofia V. Silva, F. Xavier Malcata* \\ Escola Superior de Biotecnologia, Universidade Católica Portuguesa, Rua Dr. António Bernardino de Almeida, P-4200-072 Porto, Portugal
}

\begin{abstract}
The proteolytic activity of cardosin $\mathrm{B}$, an aspartic proteinase from the thistle, Cynara cardunculus, on ovine $\alpha_{\mathrm{s}}$-caseins and $\beta$ caseins (independently or present together in sodium caseinate) was followed by urea polyacrylamide gel electrophoresis and reversed phase high performance liquid chromatography. This enzyme degraded both types of caseins, but not to the same degree. In sodium-caseinate, by $10 \mathrm{~h}$ at $30^{\circ} \mathrm{C}, \alpha_{\mathrm{s}}$-caseins were more susceptible to proteolysis by cardosin $\mathrm{B}$ than $\beta$-casein whereas, in isolated form, the reverse was observed. Sequencing of the peptides produced by hydrolysis of Na-caseinate showed that the major cleavage sites in $\alpha_{\mathrm{s} 1}$-casein were Leu156-Asp157 and Trp164-Tyr165 whereas, in $\beta$-casein, they were Leu127-Thr128, Leu165-Ser166 and Leu90-Tyr191. The bonds Trp164-Tyr165 and Leu165-Ser166 were the most susceptible to cardosin B when this enzyme acted upon isolated $\alpha_{\mathrm{s} 1}$ - and $\beta$-casein, respectively. (C) 1999 Elsevier Science Ltd. All rights reserved.
\end{abstract}

Keywords: Rennet substitute; Proteolysis; Electrophoresis; RP-HPLC

\section{Introduction}

All enzymes employed commercially in milk coagulation are aspartic proteinases, with acidic $\mathrm{pH}$ optima, and possess high levels of homology between their primary structures and of similarity between their catalytic mechanisms. Calf rennet, originally obtained from the abomasa of recent-born ruminant calves, contains chymosin (and pepsin to a lesser extent) and has been the coagulant most extensively used in cheesemaking. Shortage of supply of that traditional rennet has urged the search for new coagulating preparations for eventual use as rennet substitutes. Plant proteinases are interesting because they are natural products which can be easily extracted by aqueous infusion.

Cynara cardunculus L., a species of thistle related to the globe artichoke, can be found in dry, stony, uncultivated areas all over Portugal (Roseiro, 1991); since Roman times, aqueous extracts of its flowers have been used as a milk coagulant in the manufacture of various types of Portuguese traditional ewe's milk cheeses, especially Serra da Estrela cheese (Vieira de Sá \& Barbosa,

\footnotetext{
* Corresponding author. Tel.: + 351-2-558-0004; fax: +351-2-590-351.
}

1972; Campos, Guerra, Aguilar, Ventura \& Camacho, 1990). Flowers of $C$. cardunculus were claimed to contain one aspartic proteinase with two glycosylated subunits with molecular weights 31 and $16 \mathrm{kDa}$; that enzyme was found to induce milk coagulation through cleavage of the Phe105-Met106 bond in bovine $\kappa$-casein (Faro, 1991). However, more recent studies have shown that, in fact, there are two distinct aspartic proteinases present in the thistle, viz. cardosins A and B (Verissimo et al., 1996). These two enzymes appear chiefly in the female part of the flowers of $C$. cardunculus, i.e. in the upper area (where the ratio of the concentration of cardosin A to cardosin B is higher); in the lower part of the flowers, only cardosin B is present (Castanheira, 1998). Cardosin A consists of two subunits with apparent molecular weights 31 and $15 \mathrm{kDa}$, whereas cardosin $\mathrm{B}$ consists of two subunits with apparent molecular weights 34 and $14 \mathrm{kDa}$; it has been claimed that these enzymes are similar, in terms of specificity and activity, to chymosin and pepsin, respectively (Pires et al., 1994; Veríssimo, Esteves, Faro \& Pires, 1995). Sousa (1993) and Macedo, Faro \& Pires (1993) reported that the primary cleavage site on bovine $\alpha_{\mathrm{s} 1}$-casein is Phe23-Phe24; other peptide bonds can also be cleaved in that casein, viz. Phe145-Tyr146, Leu149-Phe150, Tyr153-Tyr154, 
Leu156-Asp157, A1a163-Trp164. Trp164-Tyr165, Tyr165-Tyr166 and Tyr166-Val167 (Macedo et al., 1993). In bovine $\alpha_{\mathrm{s} 2}$-casein, cardosins catalyse the hydrolysis of the peptide bonds Phe88-Tyr89 and Tyr95-Leu96 (Macedo et al., 1996). Sousa and Malcata (1998) monitored the primary proteolysis of ovine caseinate by both cardosins in crude aqueous extracts of $C$. cardunculus; the major cleavage sites in ovine caseinate were found to be Phe105-Met106 for $\kappa$-casein, Leu127Thr128 and Leu190-Tyr191 for $\beta$-casein, Phe23-Val24 for $\alpha_{\mathrm{s} 1}$-casein, and Phe88-Tyr89 for $\alpha_{\mathrm{s} 2}$-casein. Studies, pertaining to the independent action of cardosins $\mathrm{A}$ and B toward bovine caseins, made it clear that in $\alpha_{\mathrm{s} 1}$-casein the two enzymes cleave, primarily, the bonds Phe23Phe24, Phe153-Phe154 and Trp164-Tyr165; cardosin A also cleaves the bond Tyr165-Tyr166, whereas cardosin B cleaves, in addition, Phe150-Arg151 (Ramalho-Santos, Veríssimo, Faro \& Pires, 1996). The peptide bond Leu192-Tyr193 of $\beta$-casein is the most susceptible to attack by both cardosins; the peptide bonds Leu127Thr128 and Leu165-Ser166 can also be cleaved, but their lability is different depending on the cardosin that is used (Simões, 1998). It was also reported that both enzymes cleave the Phe105-Met106 bond in bovine $\kappa$ casein. Even though the independent action of cardosins $\mathrm{A}$ and $\mathrm{B}$ on bovine caseins has been reported, no data pertaining to the independent action of those two aspartic proteinases on ovine caseins have, to our knowledge, been made available to date.

Since proteolysis is the most important biochemical event during cheese ripening, in which the enzymes contributed by the rennet play a relevant role (especially in the first stages thereof), it is of utmost importance to evaluate the degradation patterns of caseins in model systems that mimic actual cheesemaking because of their effects on yield, texture and flavour of the final cheese. Hence, this communication reports studies on the action of cardosin B upon ovine Na-caseinate, and also upon $\alpha_{\mathrm{s}}$ - and $\beta$-caseins isolated therefrom.

\section{Materials and methods}

\subsection{Preparation of enzyme}

The method described by Veríssimo et al. (1995), with slight modifications, was followed to purify cardosin B; stigmae of dried flowers of $C$. cardunculus were separated and homogenized in a mortar and pestle at the ratio of $1 \mathrm{~g}$ of flowers per $12 \mathrm{ml}$ of aqueous $0.1 \mathrm{~mol} / 1$ citric acid ( $\mathrm{pH} 3.0)$. The homogenate was centrifuged at $6000 \mathrm{~g}$ for $20 \mathrm{~min}$, and a 2-ml aliquot of the supernatant was applied to a Highload 26/60 Sephacryl S-200 column (Pharmacia, Uppsala, Sweden), after proper conditioning, and eluted with $20 \mathrm{mmol} / 1$ Tris-HU buffer $(\mathrm{pH} 7.6)$ at a flow rate of $1.5 \mathrm{ml} / \mathrm{min}$. The fraction of the eluate corresponding to the proteinases of interest (eluted at $135 \mathrm{ml}$ ) was applied to a Mono Q HR 5/5 column (Pharmacia), from which the protein was eluted with the same buffer at a flow rate of $0.75 \mathrm{ml} / \mathrm{min}$ under a linear gradient of $0-0.5 \mathrm{~mol} / 1 \mathrm{NaCl}$ within $30 \mathrm{~min}$; the fraction corresponding to the peak eluted at $17.25 \mathrm{ml}$ was collected as cardosin B. Purity was double-checked by sodium dodecyl sulphate polyacrylamide gel electrophoresis in a Phastsystem (Pharmacia) using PhastGel homogeneous 20 .

\subsection{Quantification of protein}

Protein concentration was determined by the method of Bradford (Robyt \& White, 1990). Bovine serum albumin (Merck, Darmstadt, Germany) was used as reference in the preparation of the calibration curve.

\subsection{Preparation of sodium caseinate}

Whole ovine caseins were obtained by isoelectric precipitation from raw milk by acidification to $\mathrm{pH} 4.3$ with $6 \mathrm{~mol} / \mathrm{l} \mathrm{HCl}$, with stirring. The mixture of caseins and whey was warmed to $45^{\circ} \mathrm{C}$ and held at that temperature for $45 \mathrm{~min}$. The caseins were recovered by filtration through a clean cloth and washed several times with deionized water. The caseins were then resuspended in deionized water (to the initial volume) and $\mathrm{pH}$ was adjusted to 7.0 with $1 \mathrm{~mol} / 1 \mathrm{NaOH}$. The suspension was allowed to equilibrate at $4^{\circ} \mathrm{C}$ for at least $2 \mathrm{~h}$, and then lyophilized and stored until use.

Ovine $\alpha_{\mathrm{s}^{-}}$and $\beta$-caseins were isolated by the procedure of Mercier, Maubois, Poznanski, and RibadeauDumas (1968), with modifications; these caseins were prepared through fractionation of $\mathrm{Na}$-caseinate $(1.5 \mathrm{~g}$ per $15 \mathrm{ml} 0.01 \mathrm{~mol} / 1$ Tris-HUCl buffer) by chromatography in a column $(75 \times 2.5 \mathrm{~cm})$ containing DEAE-cellulose using $0.01 \mathrm{~mol} / 1$ Tris-HUCl buffer $(\mathrm{pH} 7.0)$, with $4.5 \mathrm{~mol} / 1 \mathrm{urea}, 0.01 \mathrm{~mol} / 1 \mathrm{imidazol}$ and $0.1 \%$ (w/v) $\beta$ mercaptoethanol as eluent, via a linear gradient $0-0.4$ $\mathrm{mol} / \mathrm{l} \mathrm{NaCl}$ within $25 \mathrm{~h}$ at the flow rate of $80 \mathrm{ml} / \mathrm{h}$; experiments were carried out at room temperature. The $\alpha_{s}$ - and $\beta$-casein fractions obtained were independently pooled, dialyzed against deionized water, lyophilized and stored until use.

\subsection{Enzymatic hydrolysis}

Whole Na-caseinate, as well as $\alpha_{\mathrm{s}}$ - and $\beta$-caseins were dissolved in $100 \mathrm{mmol} / \mathrm{l}$ phosphate buffer $(\mathrm{pH} 6.5)$ to a final concentration of $1 \%(\mathrm{w} / \mathrm{v})$ and allowed to stabilize at $30^{\circ} \mathrm{C}$; $0.05 \%(\mathrm{w} / \mathrm{v})$ sodium azide was then added to inhibit adventitious microflora. Hydrolysis, at $30^{\circ} \mathrm{C}$, was started with addition of $526 \mu \mathrm{l}$ of cardosin B extract $(180 \mu \mathrm{g} / \mathrm{ml})$ per $10 \mathrm{ml}$ of substrate solution. Samples of hydrolysates were taken after $1 \mathrm{~min}$ and 1, 3, 6 and $10 \mathrm{~h}$; the reaction was 
quenched prior to analysis by electrophoresis via addition of double-concentrated buffer at 50\% (v/v) (McSweeney, Olson, Fox, Healy \& Hojrup, 1993), and prior to analysis by RP-HPLC via heating at $95^{\circ} \mathrm{C}$ for $30 \mathrm{~min}$.

\subsection{Protein and peptide profiling by electrophoresis}

Urea polyacrylamide gel electrophoresis (urea-PAGE) (at $12.5 \%$ for the separation gel and $4 \%$ for the stacking gel, both at $\mathrm{pH}$ 8.9) was performed on samples of casein hydrolysates using the method of Andrews (1983) with modifications (Shalabi \& Fox, 1987). Electrophoresis was carried out in a Protean II xi cell vertical slab unit (Bio-Rad Laboratories, Watford, UK) using a model 1000/500 power supply (from Bio-Rad Laboratories). Gels were stained with Coomassie Blue G250 (Bio-Rad Laboratories) following the method of Blakesley and Boezi (1977); $\alpha_{s^{-}}$and $\beta$-caseins were quantified by densitometry using a Model GS-700 Imaging Densitometer (Bio-Rad Laboratoires, Hercules CA, USA).

\subsection{Peptide profiling by chromatography}

Samples of hydrolysates $(2 \mathrm{ml})$ were adjusted to $\mathrm{pH} 4.6$ by addition of $60 \mu \mathrm{l}$ of $33.3 \%(\mathrm{v} / \mathrm{v})$ acetic acid and held at that temperature for $10 \mathrm{~min}$; then, $60 \mu \mathrm{l}$ of $3.33 \mathrm{~mol} / 1$ sodium acetate was added. The samples were held for a further $10 \mathrm{~min}$ and centrifuged at $8000 \mathrm{~g}$ for $10 \mathrm{~min}$, and the supernatants were recovered for further analysis.

The method of Singh, Fox \& Healy (1995) was used to analyse the casein hydrolysates by reversed-phase high performance liquid chromatography (RP-HPLC). Chromatographic analysis was performed in a Beckman system (Beckman Instruments, San Ramon CA, USA) consisting of an autosampler (model 502), a solvent delivery system with two pumps (programable solvent module 126), a diode array detector (module 168) and a personal computer with the Gold ${ }^{\mathrm{I}}{ }^{\mathrm{m}}$ software v.6.01 for data acquisition and analysis. A Lichrosorb $250 \times 4 \mathrm{~mm}$ RP-8 (5 $\mu \mathrm{m})$ column (Merck) with a Lichrocart 4-4 guard column (Merck) was used at $30^{\circ} \mathrm{C}$. The protein was eluted at a flow rate of $1 \mathrm{ml} / \mathrm{min}$, using a mixture of two solvents: solvent A, i.e. $0.1 \%(\mathrm{v} / \mathrm{v})$ trifluoroacetic acid (TFA) in water, and solvent B, i.e. $0.1 \%(\mathrm{v} / \mathrm{v})$ trifluoroacetic acid (TFA) in acetonitrile. The gradient pattern followed was: $100 \%(\mathrm{v} / \mathrm{v})$ A over $5 \mathrm{~min}$, a linear gradient to $50 \%(\mathrm{v} / \mathrm{v}) \mathrm{B}$ over $55 \mathrm{~min}, 50 \%(\mathrm{v} / \mathrm{v}) \mathrm{B}$ over 6 min, a linear gradient to $60 \%(\mathrm{v} / \mathrm{v}) \mathrm{B}$ over $4 \mathrm{~min}$ and $60 \%(\mathrm{v} / \mathrm{v}) \mathrm{B}$ over $3 \mathrm{~min}$. Aliquots of $100 \mu \mathrm{l}$ were injected onto the column and detection was by absorbance at $214 \mathrm{~nm}$.

\subsection{Peptide sequencing}

Peptide-containing peaks were collected manually from the outlet of the RP-HPLC system and sequenced up to 5-10 N-terminal residues by the Edman iterative degradation procedure; the partial sequences thus obtained were checked against the (known) sequences of caseins to determine the peptide bonds cleaved by the proteinases.

\section{Results and discussion}

The electrophoretic patterns of hydrolysates of ovine caseinate, isolated $\beta$-casein and isolated $\alpha_{\mathrm{s}}$-casein are shown in Figs. 1-3, respectively. The percentage of $\alpha_{\mathrm{s}}$ and $\beta$-caseins hydrolysed, both in ovine caseinate and in isolated form, are shown in Fig. 4. Two main groups of ovine milk caseins were identified, a realization that is consistent with previous observations (Richardson \& Creamer, 1976); the group with higher mobility represents the $\alpha_{\mathrm{s}}$-casein region, whereas that with lower mobility is the $\beta$-casein region (see Figs. 1-3).

In caseinate hydrolysates, degradation of either $\alpha_{s^{-}}$or $\beta$-caseins was observed as early as by $1 \mathrm{~min}$ (see lane 2 of Fig. 1); it was apparent that $\alpha_{\mathrm{s}}$-caseins were hydrolysed faster than $\beta$-caseins (see Fig. 4), reaching percent degradations of 76 and $52 \%$, respectively, by $1 \mathrm{~min}$. It is also clear from inspection of Fig. 1 that, by this time, only a small amount of $\alpha_{\mathrm{s}}$-casein remains unhydrolysed. Two bands appear ahead of $\beta$-casein (see bands $\mathrm{A}$ and $\mathrm{B}$ in lane 2 of Fig. 1), as well as three bands with higher electrophoretic mobilities than $\alpha_{\mathrm{s}}$-caseins (see bands $\mathrm{C}$, $\mathrm{D}$ and $\mathrm{E}$ in lane 2 of Fig. 1). Bands A, B, C, and D tended to disappear as incubation progressed, while band $\mathrm{E}$ and other bands with mobilities between those of $\alpha_{\mathrm{s}}$-caseins

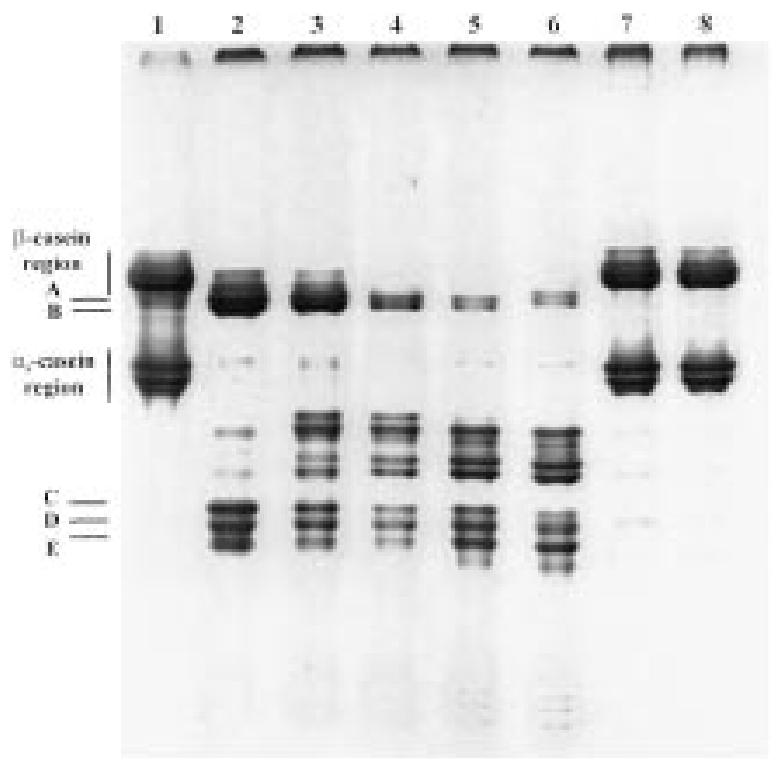

Fig. 1. Urea-PAGE electrophoregram, of ovine Na-caseinate after hydrolysis by cardosin B for $1 \mathrm{~min}$ and 1, 3, 6 and $10 \mathrm{~h}$ (lanes 2-6). Lane 1 contains native ovine Na-caseinate, and lanes 7 and 8 contain ovine Na-caseinate after incubation for $1 \mathrm{~min}$ and $10 \mathrm{~h}$, respectively, in the absence of enzyme, all included as controls. 


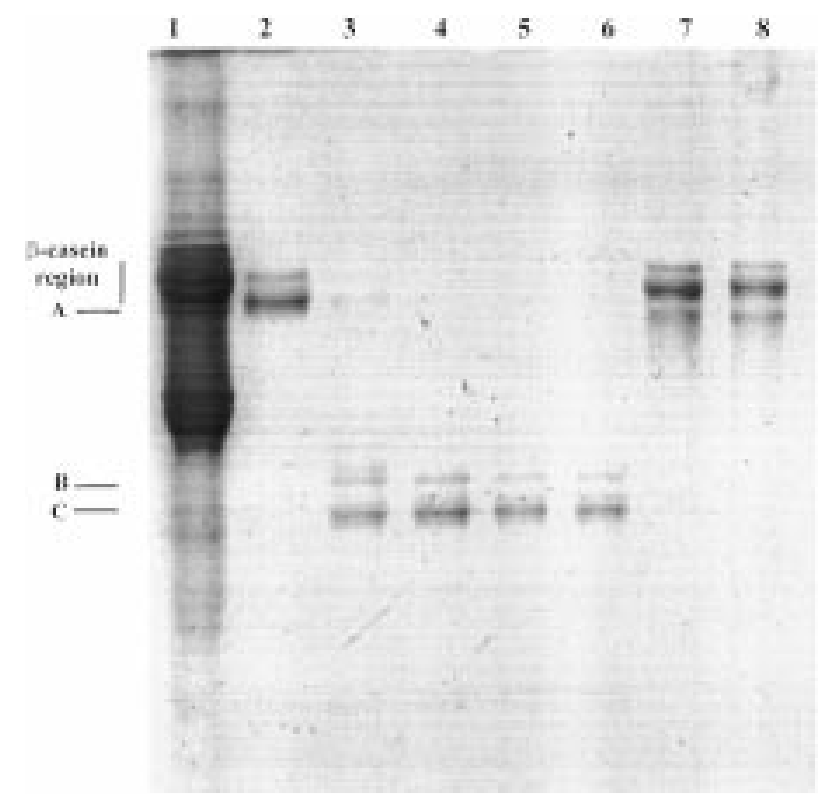

Fig. 2. Urea-PAGE electrophoregram of isolated $\beta$-casein after hydrolysis by cardosin B for $1 \mathrm{~min}$ and $1,3,6$ and $10 \mathrm{~h}$ (lanes 2-6). Lane 1 contains native ovine Na-caseinate, and lanes 7 and 8 contain ovine $\beta$-casein after incubation for $1 \mathrm{~min}$ and $10 \mathrm{~h}$, respectively, in the absence of enzyme, all included as controls.

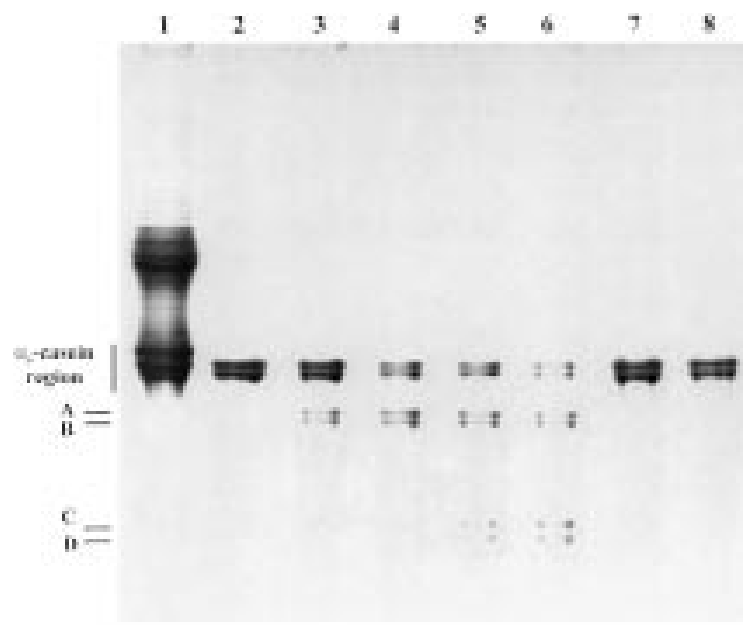

Fig. 3. Urea-PAGE electrophoregram of isolated $\alpha_{\mathrm{s}}$-casein after hydrolysis by cardosin B for $1 \mathrm{~min}$ and 1, 3, 6 and $10 \mathrm{~h}$ (lanes 2-6). Lane 1 contains native ovine Na-caseinate, and lanes 7 and 8 contain ovine $\alpha_{\mathrm{s}}$-casein after incubation for $1 \mathrm{~min}$ and $10 \mathrm{~h}$, respectively, in the absence of enzyme, all included as controls.

and of band $\mathrm{C}$ became more intense (see lanes 3-6 of Fig. 1). $\alpha_{\mathrm{s}}$-Caseins were hydrolysed more rapidly than $\beta$ caseins, up to 100 and $87 \%$, respectively, by $10 \mathrm{~h}$. It should be noted that a residual amount of proteinaceous material still remains by $10 \mathrm{~h}$; however, it is probably not accounted for by $\alpha_{\mathrm{s}}$-casein, but is, rather, a polypeptide resulting from degradation of $\alpha_{\mathrm{s}}$-casein or of $\beta$-casein. This observation is comparable to what happens in cheese, since it has also been claimed that $\beta$-caseins were less susceptible to proleolysis than $\alpha_{\mathrm{s}}$-caseins in the manufacture of raw ewe's milk cheese that use extracts of C. cardunculus as coagulant (Sousa \& Malcata, 1997).

With respect to cleavage of isolated $\beta$-caseins by car$\operatorname{dosin} \mathrm{B}$, one band is apparent ahead of the $\beta$-casein region, by 1 min of hydrolysis, which eventually vanishes as incubation time elapses (see band A in lanes 2-6 of Fig. 2). This band is comparable to that of bovine $\beta$-I casein (Sousa, 1993), which results from cleavage of both Leu192-Tyr193 and A1a189-Phe190 (Macedo et al., 1993; Sousa, 1993). In ovine $\beta$-casein, the corresponding breakdown sites are Leu190-Tyr191 and Ala187-Phe188 (Whyte, 1995). Studies encompassing the action of cardosin B on separated bovine $\beta$-caseins showed that the Leu192-Tyr193 bond was also cleaved, as well as Leu127-Thr128 and Leu165-Ser166 (Simões, 1998). After $1 \mathrm{~h}$ of hydrolysis, two bands displaying higher electrophoretic mobilities than that of band A could be observed, which became more intense with time (see bands B and C in lanes 3-6 of Fig. 2); by $10 \mathrm{~h}$ of incubation, $\beta$-caseins were fully degraded. The state of aggregation and globular conformation of caseins seems to affect proteolysis (Dalgleish, 1987); in fact, the aforementioned results show that $\beta$-caseins are, in separated (and possibly denaturated) form, more quickly and extensively degraded than in caseinate (and possibly structured) form (see Fig. 4). The higher resistance to hydrolysis in the latter case may be attributed to the complex set of interactions within caseins in $\mathrm{Na}-$ caseinate (which encompass native $\alpha_{\mathrm{s}}$-caseins, $\beta$-caseins and $\kappa$-caseins), and also to the high amount of fat in ovine milk, which changes accessibility of the enzyme to the labile peptide bonds.

When in isolated form, $\alpha_{\mathrm{s}}$-caseins were extensively hydrolysed and reached a degradation level of $81 \%$ by $10 \mathrm{~h}$ of incubation. Two bands, displaying higher mobilities than $\alpha_{\mathrm{s}}$-caseins, were apparent after $1 \mathrm{~h}$ of incubation and their density increased as hydrolysis time elapsed (see bands A and B in lanes 3-6 of Fig. 3). Two other bands, $\mathrm{C}$ and $\mathrm{D}$; appeared by $6 \mathrm{~h}$ of reaction and remained still thereafter. Despite reports by Dalgleish (1987), $\alpha_{\mathrm{s}}$-caseins were hydrolysed to a lesser extent in isolated form than in caseinate form by cardosin B. These results might be rationalized in view of the spatial distribution of caseins within the caseinate structure: the putative bulky location of $\alpha_{\mathrm{s}}$-caseins (in a more hydrophobic environment) may favour hydrolysis when compared with isolated (and hence fully exposed) $\alpha_{\mathrm{s}}$-caseins. Further work is, however, needed in order to fully clarify this point. It should be emphasized that differences observed between degradation patterns of $\alpha_{\mathrm{s}^{-}}$and $\beta$ caseins (present together in $\mathrm{Na}$-caseinate or separated from one another) are not at all due to a dilution factor, since the concentration of substrate protein was in all cases normalized by its initial concentration. 

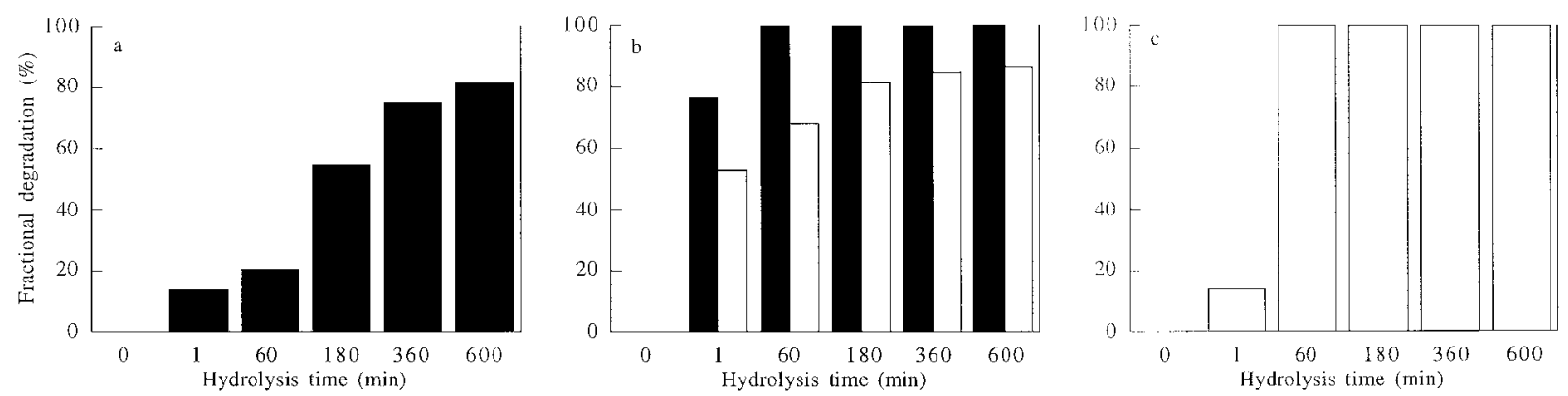

Fig. 4. Percentage of hydrolysis of ovine caseins $\left(\alpha_{\mathrm{s}}\right.$-casein: $\square$; $\beta$-casein: $\left.\square\right)$ in isolated form $\left(\alpha_{\mathrm{s}}\right.$-casein: a, $\beta$-casein: c), and in the presence of each other in Na-caseinate form (b), effected by cardosin B, versus incubation time.
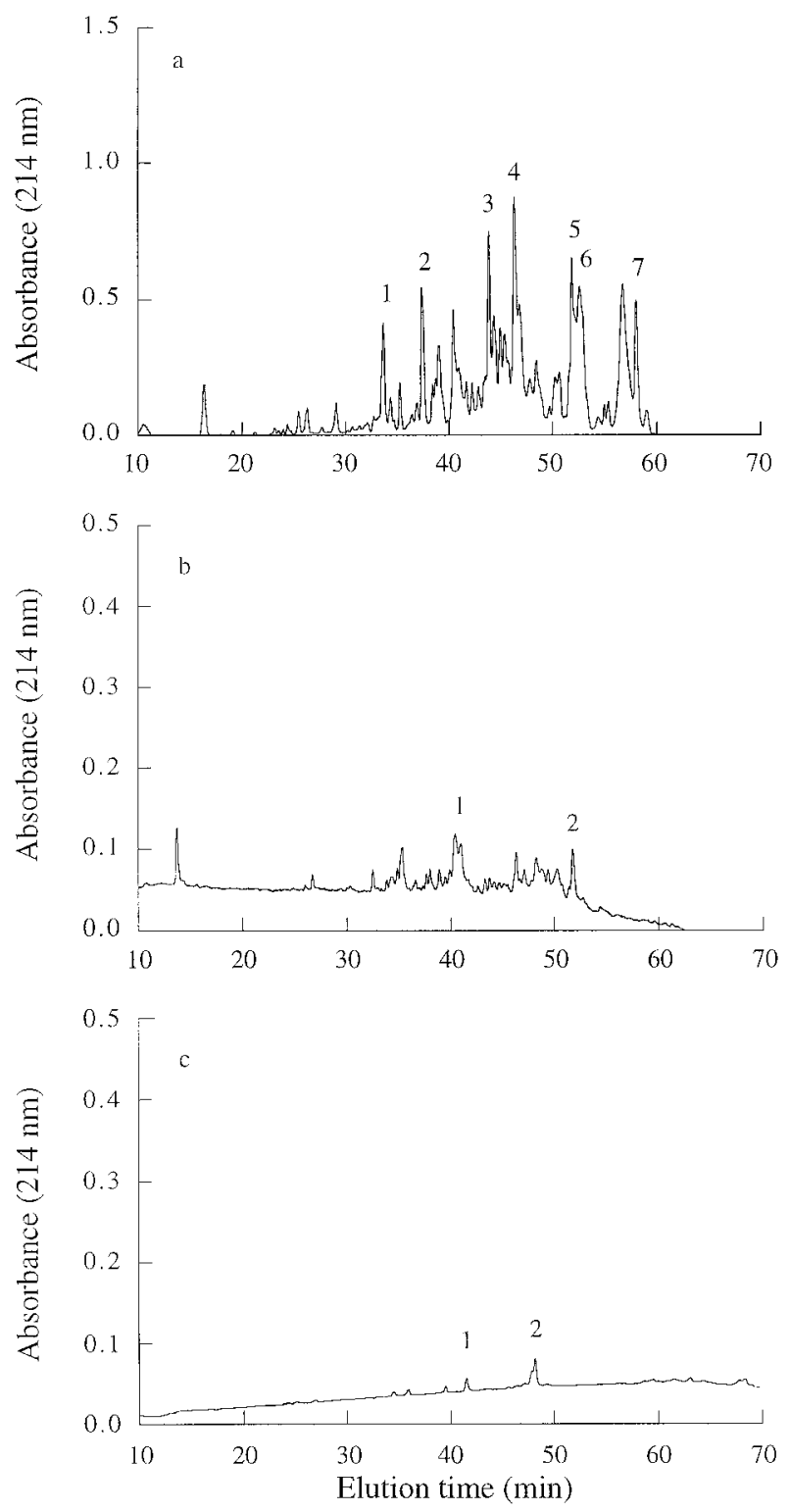

Fig. 5. RP-HPLC peptide profile of ovine sodium caseinate (a), isolated $\beta$-casein (b) and isolated $\alpha_{\mathrm{s}}$-casein (c) by $10 \mathrm{~h}$ of hydrolysis carried out by cardosin $\mathrm{B}$.
The RP-HPLC peptide profiles of hydrolysates of ovine caseinate, isolated ovine $\beta$-casein and isolated ovine $\alpha_{\mathrm{s}}$-casein, obtained via action of cardosin B for 10 $\mathrm{h}$, are shown in Fig. 5. Seven major peaks were visible in the peptide profile of ovine caseinate hydrolysate. Sequencing of those peptides indicated that cardosin B can cleave peptide bonds in both $\alpha_{\mathrm{s}}$ and $\beta$-caseins. The $\mathrm{N}$-terminal sequences of the peptides, designated as 1 $\left[\alpha_{1}-(\mathrm{f} 157-*)\right], 3$ and $5\left[\alpha_{\mathrm{s} 1}-(\mathrm{f} 165-*)\right]$ in Fig. 5a, indicated that $\alpha_{\mathrm{s} 1}$-casein was cleaved by cardosin $\mathrm{B}$ at bonds Leu156-Asp157 and Trp164-Tyr165. The N-terminal sequence of ovine $\alpha_{\mathrm{s} 1}$-casein was identified in peptide 4 . $\beta$-Casein was cleaved by cardosin B at Leu165-Ser166, Leu190-Tyr191 and Leu127-Thr128, as derived from the $\mathrm{N}$-terminal sequence of the peptides denoted as 2 $\left[\beta-(\mathrm{f} 166-*), 6\left[\beta-\left(\mathrm{f} 191-^{*}\right)\right]\right.$ and $7\left[\beta-\left(\mathrm{f} 128-^{*}\right)\right]$, respectively (Fig. 5a). The peptide bonds Leu190-Tyr191 and Leu127-Thr128 were also claimed (Sousa \& Malcata, 1998) to be broken in ovine sodium caseinate by cardosins A and B mixed with one another.

With respect to isolated $\beta$-casein, the $\mathrm{N}$-terminal sequence of peptide $2[\beta-f 166-*)]$ (Fig. $5 b$ ) indicated that ovine $\beta$-casein was broken by cardosin $\mathrm{B}$ at peptide bond Leu165-Ser166; Leu165-Ser166 was also cleaved by cardosin B in bovine $\beta$-casein, as well as Leu127Thr128 and Leu192-Tyr193 (Simões, 1998).

With respect to isolated $\alpha_{\mathrm{s}}$-caseins, two major peaks became apparent by $10 \mathrm{~h}$ of hydrolysis (Fig. 5c). $\alpha_{\mathrm{s} 1^{-}}$ Casein was cleaved by cardosin B at the peptide bond Trp164-Tyr165, as apparent from sequencing of the peptide designated as $2\left[\alpha_{\mathrm{s} 1}-(\mathrm{f} 165-*)\right]$. The corresponding bond cleaved in bovine $\alpha_{\mathrm{s} 1}$-casein is Trp164-Tyr165; the bonds Phe23-Phe24, Trp153-Tyr154 and Phe150Arg151 can, in addition, be cleaved (Ramalho-Santos et al., 1996).

\section{Conclusions}

Significant differences exist with respect to the action of cardosin B from C. cardunculus upon ovine $\alpha_{\mathrm{s}^{-}}$and 
$\beta$-caseins. When $\alpha_{s^{-}}$and $\beta$-caseins are present together in sodium-caseinate, $\alpha_{\mathrm{s}}$-caseins are much more susceptible to proteolysis than $\beta$-caseins, whereas the reverse is observed when the caseins are tested independently. In sodium caseinate, $\alpha_{\mathrm{s} 1}$-casein is cleaved by cardosin B at bonds Leu156-Asp157 and Trp164-Tyr165, whereas $\beta$ casein is cleaved at peptide bonds Leu127-Thr128, Leu165-Ser166 and Leu190-Tyr191. The bonds Leu165Ser166 and Trp164-Tyr165 are cleaved by cardosin B in isolated $\beta$-casein and isolated $\alpha_{\mathrm{s} 1}$-casein, respectively.

\section{Acknowledgements}

The authors are grateful to Dr. José Empis (Instituto Superior Técnico, Lisboa, Portugal) for cosupervision within the scope of the graduate program where author Silva was enrolled. Financial support for author Silva was provided by an M.Sc. fellowship (BM/8824/96), issued by PRAXIS XXI (FCT, Potugal). Partial financial support for this work was provided by grants through projects PROTOLACTIS: PROdução, por Tecnologias Optimizadas, de LACticinios TradicionaIS (PAMAF, Portugal) and IMPACTO: Investigação dirigida ao Melhoramento do queijo serra Por integrAção de abordagens Científicas e TecnOlógicas (PRAXIS XXI, Portugal), both coordinated by author Malcata.

\section{References}

Andrews, A. T. (1983). Proteinases in normal bovine milk and their actions on caseins. Journal of Dairy Research, 50, 45-55.

Blakesley, R. W., \& Boezi, J. A. (1977). A new staining technique for proteolysis in polyacrylamide gels using Coomassie Brilliant Blue G250. Annals of Biochemistry, 82, 580-581.

Campos, R., Guerra, R., Aguilar, M., Ventura, O., \& Camacho, L. (1990). Chemical characterization of proteases extracted from wild thistle (Cynara cardunculus). Food Chemistry, 35, 89-97.

Castanheira, P. M. D. (1998). Distribuição diferencial das cardosinas A e B ao longo do pistilo de Cynara cardunculus L. M.Sc. thesis, Universidade de Coimbra, Coimbra, Portugal.

Dalgleish, D. E. (1987). The enzymatic coagulation of milk. In: P. F. Fox, Cheese: chemistry, physics and microbiology (vol. 1, pp. 63-96). London: Elsevier Applied Science.

Faro, C. (1991). Purificação e caracterização físico-química da protease de Cynara cardunculus L. Ph.D. thesis, Universidade de Coimbra, Coimbra, Portugal.

Macedo, I. Q., Faro, C. J., \& Pires, E. M. (1993). Specificity and kinetics of the milk-clotting enzyme from cardoon (Cynara cardunculus L.) toward bovine $\kappa$-casein. Journal of Agricultural and Food Chemistry, 41, 1537-1540.

Macedo, I. Q., Faro, C. J., \& Pires, E. V. (1996). Caseinolytic specificity of cardosin, an aspartic protease from the cardoon Cynara cardunculus L.; action on bovine $\alpha_{\mathrm{s}^{-}}$and $\beta$-casein and comparison with chymosin. Journal of Agricultural and Food Chemistry, 44, 42-47.

McSweeney, P. L. H., Olson, N. F., Fox, P. F., Healy, A., \& Hojrup, P. (1993). Proteolytic specificity of chymosin on bovine $\alpha_{\mathrm{s} 1}$-casein. Journal of Dairy Research, 60, 401-412.

Mercier, J. C., Maubois, J. L., Poznanski, S., \& Ribadeau-Dumas, B. (1968). Fractionnement préparatif des caséines de vache et brebis par chromatographie sur D.E.A.E. cellulose, en milieu urée et 2mercaptoéthanol. Bull Soc. Chim. Biol., 50, 521-530.

Pires, E., Faro, C., Macedo, I., Esteves, C., Morgado. J., Verissimo, P., Dias-Pereira, \& Gomes, D. (1994). Flor do cardo versus quimosina no fabrico de queijos artesanais. Revista da Sociedade Portuguesa de Quimica, 54, 66-68.

Ramalho-Santos, M., Veríssimo, P., Faro, C., \& Pires, E. (1996). Action on bovine $\alpha_{\mathrm{s} 1}$-casein of cardosins $\mathrm{A}$ and $\mathrm{B}$, aspartic proteinases from the flowers of the cardoon Cynara cardunculus L. Biochimica et Biophysica Acta, 1297, 83-89.

Richardson, B. C., \& Creamer, L. K. (1976). Comparative micelle structure. V. The isolation and characterization of the major ovine caseins. New Zealand Journal of Dairy Science and Technology, 11, $46-53$.

Robyt, J. F., White, B. J. (1990). In Biochemical techniques-theory and practice (pp. 213-252). Prospect Heights, IL:Waveland Press.

Roseiro, M. L. B. (1991). Ewe's milk cheesemaking in Portugal using a vegetable rennet (a review). Sheep Dairy News, 8, 65-80.

Shalabi, S. I, \& Fox, P. F. (1987). Electrophoretic analysis of cheese: comparison of methods. Irish Journal of Food Science and Technology, 11, 135-151.

Simões, I. I. G. (1998). Caracterização molecular da acção das cardosinas A e B sobre caseínas $\beta$ e $\kappa$ bovinas. M.Sc. thesis, Universidade de Coimbra, Coimbra, Portugal.

Singh, T. K., Fox, P. F., \& Healy, A. (1995). Water-soluble peptides in Cheddar cheese: isolation and identification of peptides in the diafiltration retentate of the water-soluble fraction. Journal of Dairy Research, 62, 629-640.

Sousa, M. J. C. F. (1993). Plant rennet substitute from flowers of Cynara cardunculus. M.Sc. thesis, National University of Ireland, Cork, Ireland.

Sousa, M. J., \& Malcata, F. X. (1997). Comparison of plant and animal rennets in terms of microbiological, chemical, and proteolysis characteristics of ovine cheese. Journal of Agricultural and Food Chemistry, 45, 74-81.

Sousa, M. J., \& Malcata, F. X. (1998). Proteolysis of ovine and caprine caseins in solution by enzymatic extracts from flowers of Cynara cardunculus. Enzyme and Microbial Technology, 22, 305-314.

Veríssimo, P., Esteves, C., Faro, C., \& Pires, E. (1995). The vegetable rennet of Cynara cardunculus L. contains two proteinases with chymosin and pepsin-like specificities. Biotechnology Letters, 17, 621626.

Veríssimo, P., Faro, C., Moir, A. J. G., Lin, Y., Tang, J., \& Pires, E. (1996). Purification, characterization and partial amino acid sequencing of two new aspartic proteinases from fresh flowers of Cynara cardunculus L. European Journal of Biochemistry, 235, 762768.

Vieira de Sá, F., \& Barbosa, M. (1972). Cheese-making with a vegetable rennet from Cardo (Cynara cardunculus). Journal of Dairy Research, 39, 335-343.

Whyte, N. H. (1995). Proteolysis of bovine and ovine caseins by lamb and calf chymosin. M.Sc. thesis, National University of Ireland, Cork, Ireland. 